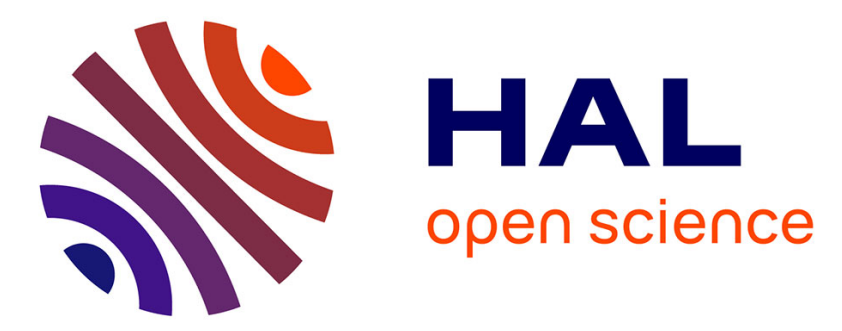

\title{
Hierarchically-organized, well-dispersed hydroxyapatite-coated magnetic carbon with combined organics and inorganics removal properties
}

Huihui Yang, Qiang Liu, Sylvie Masse, Hao Zhang, Laifeng Li, T. Coradin

\section{To cite this version:}

Huihui Yang, Qiang Liu, Sylvie Masse, Hao Zhang, Laifeng Li, et al.. Hierarchically-organized, welldispersed hydroxyapatite-coated magnetic carbon with combined organics and inorganics removal properties. Chemical Engineering Journal, 2015, 275, pp.152-159. 10.1016/j.cej.2015.04.026 . hal01142009

\author{
HAL Id: hal-01142009 \\ https: / hal.sorbonne-universite.fr/hal-01142009
}

Submitted on 14 Apr 2015

HAL is a multi-disciplinary open access archive for the deposit and dissemination of scientific research documents, whether they are published or not. The documents may come from teaching and research institutions in France or abroad, or from public or private research centers.
L'archive ouverte pluridisciplinaire $\mathbf{H A L}$, est destinée au dépôt et à la diffusion de documents scientifiques de niveau recherche, publiés ou non, émanant des établissements d'enseignement et de recherche français ou étrangers, des laboratoires publics ou privés. 


\section{Hierarchically-organized, well-dispersed hydroxyapatite-coated magnetic} carbon with combined organics and inorganics removal properties

Huihui Yang ${ }^{\mathrm{a}}$, Qiang Liu ${ }^{\mathrm{a}}$, Sylvie Masse ${ }^{\mathrm{b}}$, Hao Zhang ${ }^{\mathrm{a}}$, Laifeng Li ${ }^{\mathrm{a} *}$ and Thibaud Coradin ${ }^{\mathrm{b} *}$

${ }^{a}$ Key Laboratory of Cryogenics, Technical Institute of Physics and Chemistry, Chinese Academy of Science, Beijing 100190, PR China

Prof. S. Masse, Prof. T. Coradin

${ }^{\mathrm{b}}$ CNRS, UMR 7574, Chimie de la Matière Condensée de Paris, F-75005 Paris, France

Sorbonne Universités, UPMC Universités Paris 06, UMR 7574, Chimie de la Matière

Condensée de Paris, F-75005 Paris, France

* Corresponding anthors:

Laifeng $L i$

Tel:+86 10 82543698,Fax:+8610 82543700,Email: laifengli@mail.ipc.ac.cn

\section{Thibaud Coradin}

Tel+33 144274018; Fax:+33 144271443,Email: thibaud.coradin@upmc.fr 


\begin{abstract}
Novel hierarchically-organized magnetic microspheres have been successfully developed that consist of an aqueous hollow core, a magnetic porous $\mathrm{Fe}_{3} \mathrm{O}_{4}$-carbon layer and a well-define hydroxyapatite (HAp) shell. The hollow magnetic carbon microspheres were prepared by ultrasonic spray pyrolysis and coated with HAp using a biomimetic approach. The resulting powders exhibit micro- and meso-porosity. The removal capacity of the composite spheres towards an antibiotic (ampicilin), a rare-earth ion $\left(\mathrm{La}^{3+}\right)$ and two heavy metals $\left(\mathrm{Hg}^{2+}\right.$ and $\left.\mathrm{Pb}^{2+}\right)$ has been studied and compared with that of the individual components. The dual organic-inorganic affinity of the magnetic HAp/carbon conjugates was demonstrated, with synergetic effects being evidenced for heavy metal removal enlightening their potentialities in wastewater treatment.
\end{abstract}

\title{
Keywords:
}

water treatment, superconducting separation, porous spheres, carbon, hydroxyapatite 


\section{Introduction}

Long-term exposure to polluted waters has significant detrimental effects on human health and, in particular, can cause diseases, such as lungs, bladder, kidneys and skin cancer. The development of low-cost and efficient methods for wastewater treatment is therefore an urgent and highly relevant research area [1-3]. Under normal circumstances, water treatment involves a series of physical, chemical and biological processes [4,5]. A critically timeconsuming step is the coagulation/adsorption process where pollutants are precipitated in a particulate form or adsorb on powders as this often requires a subsequent decantation period [6]. Compared to traditional treatment methods, superconducting magnetic separation of sorbents has several advantages, such as the lower investment, smaller area occupied, and shorter period of processing $[7,8]$.

Magnetic materials, named as seeds, play a key dual role in the superconducting magnetic separation technology: they need to efficiently immobilize the pollutants and at the same time must be easily separated by application of an external field [9]. Iron and iron oxide nanoparticles are well-suited for this application due to their surface affinity and redox degradation activity towards a wide range of organic and inorganic contaminants $[10,11]$. To avoid issues related to colloidal stability and handling of nanomaterials, 3D hierarchical nanostructures have been developed [12]. As an alternative, it is possible to design (nano)composite powders where the magnetic nanoparticles are associated with a sorbent phase [13]. In the field of water remediation, calcium phosphates and carbons represent two important classes of materials with high affinity for inorganic and organic contaminants, respectively $[14,15]$. HAp and carbon nanoparticles have already been previously individually associated with iron and iron oxide colloids for remediation [16-19]. However, to our knowledge, the corresponding triphasic system organized within a single composite structure has never been described so far. 
Looking for a cheap, easily-scalable source of magnetic carbon, we focused our attention on ultrasonic spray pyrolysis (USP) as a continuous, one-step method to obtain porous iron oxide/carbon microspheres [20,21]. The nebulization process is based on the formation of a mist from the aqueous solution under the high-frequency ultrasound radiation. The gas flow carries the droplets into a furnace, where solvent evaporation and precursor decomposition occur, producing the $\mathrm{C} / \mathrm{Fe}_{3} \mathrm{O}_{4}$ composite. In parallel, in order to achieve the controlled integration of the calcium phosphate phase to these microspheres, we applied a biomimetic approach previously developed for the coating of iron oxide particles with HAp [22,23]. This method relies on a pre-coating of a core particle by an acidic aminoacid, followed by addition of calcium and phosphate ions whose precipitation is confined on the particle surface.

Following these approaches, we have prepared here $\mathrm{HAp} @ \mathrm{C} / \mathrm{Fe}_{3} \mathrm{O}_{4}$ core-shell three-phasic composite microspheres. We could evidence that the biomimetic interfacial mineralization allows for confinement of the apatite phase on the microsphere surface. The influence of mineralization on the microsphere porosity and its magnetic properties was studied. The adsorption behavior of bare and coated microspheres towards key pollutants, i.e. the antibiotic ampicillin, $\mathrm{La}^{3+}, \mathrm{Hg}^{2+}$ and $\mathrm{Pb}^{2+}$, was evaluated and compared. This allows for a discussion of the interplay between the different components within the composite architecture, enlightening their potential applications for water treatment.

\section{Material and methods}

\subsection{Preparation and characterization of $\mathrm{HAp} @ \mathrm{C} / \mathrm{Fe}_{3} \mathrm{O}_{4}$ microspheres}

Magnetic carbon microspheres were prepared according to the literature with some modifications [20]. Typically, an aqueous precursor solution was prepared by dissolving glucose (4 g) and ferrous chloride tetrahydrate $(3 \mathrm{~g})$ in $100 \mathrm{~mL}$ deionized water. The precursor solution was nebulized using a commercially-available household ultrasonic 
humidifier $(1.7 \mathrm{MHz})$ into a quartz tube placed inside a furnace $\left(700{ }^{\circ} \mathrm{C}\right)$. The flow rate of inert gas $\left(\mathrm{N}_{2}\right.$ or Ar) was typically 1 SLPM. The residence time through the furnace was controlled by the gas flow rate and was typically a few seconds. The resulting dark particles were collected into ethanol-filled bubblers and recovered by magnetic separation. These $\mathrm{C} / \mathrm{Fe}_{3} \mathrm{O}_{4}$ products were washed three times with ethanol.

For hydroxyapatite deposition (Fig. 1), $1 \mathrm{~g}$ of the $\mathrm{C} / \mathrm{Fe}_{3} \mathrm{O}_{4}$ composite powder was first dispersed into $40 \mathrm{~mL}$ of a $1 \mathrm{~mol} \mathrm{~L}^{-1} \mathrm{~L}$-aspartic acid solution at $80{ }^{\circ} \mathrm{C}$ for $2 \mathrm{~h}$, followed by washing and re-suspension into $40 \mathrm{~mL}$ deionized water (sample $\mathrm{C} / \mathrm{Fe}_{3} \mathrm{O}_{4} / \mathrm{A}$ ) [23]. In parallel, $\mathrm{Ca}(\mathrm{OH})_{2}(0.01 \mathrm{~mol}, 0.748 \mathrm{~g})$ was dissolved in $100 \mathrm{~mL}$ of an ethanol-water mixture $(50: 50 \%$, v/v) under stirring for $3 \mathrm{~h}$. Then $60 \mathrm{~mL}$ of a $\mathrm{NH}_{4} \mathrm{H}_{2} \mathrm{PO}_{4}(0.006 \mathrm{~mol}, 0.67 \mathrm{~g})$ solution was added and the mixture was stirred for $1 \mathrm{~h}$. After this delay, the $\mathrm{C} / \mathrm{Fe}_{3} \mathrm{O}_{4} / \mathrm{A}$ suspension was quickly transferred into the mixture and the solution was aged for $24 \mathrm{~h}$. The powder was recovered by magnetic separation, thoroughly washed with deionized water and dried at $60{ }^{\circ} \mathrm{C}$ under vacuum overnight.

X-Ray Diffraction (XRD) studies were performed on a Philips PW131 diffractometer, in a $2 \theta$ range from $10^{\circ}-70^{\circ}$. Transmission Electron Microscopy (TEM) imaging was performed on a JEM-2100, operating at $120 \mathrm{kV}$. Scanning Electron Microscopy (SEM) imaging was conducted on a Hitachi S-4800, operating at $5 \mathrm{kV} . \mathrm{N}_{2}$ sorption studies were performed at $77 \mathrm{~K}$ using a Quantachrome Quadrasorb SI-MP equipment. Thermogravimetric Analysis (TGA) measurements were performed on a Diamond TG/DTA (Perkin Elmer). Magnetic measurements were performed using a vibrating sample magnetometer (VSM) (Lake Shore 7410) in an applied magnetic field of $\pm 10 \mathrm{kOe}$ at room temperature. X-ray photoelectron spectra (XPS) were recorded on a ESCALAB 250Xi photoelectron spectrometer. The monochromated AlK X-radiation was used as the excitation source. 


\subsection{Adsorption experiments}

Solutions with concentrations ranging from 0 to $5 \mathrm{mmol} \mathrm{L}^{-1}$ were prepared from ampicillin (Sigma), $\mathrm{La}\left(\mathrm{NO}_{3}\right)_{3}, \mathrm{HgCl}_{2} \cdot 6 \mathrm{H}_{2} \mathrm{O}$ and $\mathrm{Pb}\left(\mathrm{NO}_{3}\right)_{2} \cdot 6 \mathrm{H}_{2} \mathrm{O}$ by dissolution in deionized water $(\mathrm{pH}$ 6). For kinetics study, 0.2 g of $\mathrm{HAp}, \mathrm{C} / \mathrm{Fe}_{3} \mathrm{O}_{4}$ or $\mathrm{HAp} @ \mathrm{C} / \mathrm{Fe}_{3} \mathrm{O}_{4}$ were added to $100 \mathrm{~mL}$ of the solutions and stirred with a orbital shaker at $200 \mathrm{rpm}$ at $25^{\circ} \mathrm{C}$. Sorption isotherms were obtained using $0.1 \mathrm{~g}$ of the sorbent powders suspended in $50 \mathrm{~mL}$ of the contaminated solution and stirred in the same conditions for $24 \mathrm{~h}$ at $25{ }^{\circ} \mathrm{C}$. For metal ion solutions, additional experiments were performed at $\mathrm{pH}=4$ and 8 by addition of $\mathrm{HCl}$ and $\mathrm{NaOH}$, respectively. In all experiments, after magnetic separation, the $\mathrm{La}^{3+}, \mathrm{Hg}^{2+}, \mathrm{Pb}^{2+}$ and $\mathrm{Ca}^{2+}$ content of the supernatant was determined by inductively coupled plasma spectrometry (ICP) (Varian 710ES) and residual ampicillin content was analyzed with a UV-Vis spectrophotometer (Varian Cary 5000) at $\lambda=210 \mathrm{~nm}$.

The Freundlich and Langmuir adsorption isotherm models were used to fit the experimental data. The Langmuir model takes the following form:

$$
q_{e}=q_{\max } \frac{K_{l} C_{e}}{1+K_{l} C_{e}}
$$

where $q_{e}$ is the amount of ampicilin or metal ions adsorbed at equilibrium ( $\left.\mathrm{mmol} \mathrm{g}^{-1}\right), q_{\max }$ is the maximum sorption capacity $\left(\mathrm{mmol} \mathrm{g}^{-1}\right), \mathrm{K}_{\mathrm{l}}$ is the Langmuir constant $\left(\mathrm{L} \mathrm{mg}^{-1}\right)$, that is related to the binding energy of the species to the active site and $C_{e}$ is the equilibrium concentration $\left(\mathrm{mg} \mathrm{L}^{-1}\right)$. The linear form of Freundlich equation can be expressed as follows:

$$
\log q_{e}=\frac{1}{n} \log C_{e}+\log K_{f}
$$

where $q_{e}$ is the amount adsorbed at equilibrium $\left(\mathrm{mmol} \mathrm{g}^{-1}\right), \mathrm{K}_{\mathrm{f}}\left(\mathrm{mmol} \mathrm{g}^{-1}\right)$ is the Freundlich constant indicating the adsorption capacity and $1 / n$ is indicative of the intensity of the 
adsorption reaction. When $1 / n$ values are in the range $0.1<1 / n<1$, the adsorption process is considered favorable.

All experiments in this study were performed in triplicate and the error range was always below $10 \%$. The results were given as average values, except for values obtained by modeling.

\section{Results and discussion}

\subsection{Preparation and characterization of hydroxyapatite-coated magnetic carbon}

\section{microspheres}

Nebulization and heating of the glucose- $\mathrm{FeCl}_{2}$ solution led to microspheres with diameter ranging from $400 \mathrm{~nm}$ to ca. $1 \mu \mathrm{m}$ as visualized by SEM in Fig. 2(a). In most cases, the spheres were intact but some fractured particles revealed their hollow structure (inset of Fig. 2(c)). TEM images were consistent with SEM evidencing that nanoparticles are mostly located on the edge of the microspheres (Fig. 2(e)). XRD patterns of the materials indicated that these nanoparticles consist of magnetite $\mathrm{Fe}_{3} \mathrm{O}_{4}$ or maghemite $\gamma-\mathrm{Fe}_{2} \mathrm{O}_{3}$ (Fig. 3(a)). The $\mathrm{Fe}$ $2 \mathrm{p}$ peak of the XPS spectra showed two main signals at $c a .711 \mathrm{eV}$ and $724 \mathrm{eV}$, characteristics of the $\mathrm{Fe}_{3} \mathrm{O}_{4}$ phase (Fig. 3(b)) [24]. TGA measurements indicated that the microspheres contain $51 \pm 1$ wt $\%$ of carbon $($ Fig. $4(\mathbf{b}))$.

After deposition of L-aspartic acid, the addition of the microspheres to a solution of calcium and phosphate salts led to the formation of rod-like crystals protruding from the particle surface (Fig. 2(b),2(d)). TEM allowed a more detailed observation of the newly-formed mineral outer layer (thickness $c a .50-100 \mathrm{~nm}$ ), with rods apparently growing on the external surface of $\mathrm{C} / \mathrm{Fe}_{3} \mathrm{O}_{4}$ (Fig. 2(f)). XRD patterns of the recovered powders showed new peaks corresponding to the hydroxyapatite $\left(\mathrm{HAp}, \mathrm{Ca}_{10}\left(\mathrm{PO}_{4}\right)_{6}(\mathrm{OH})_{2}\right)$ structure (Fig. 3(a)). The XPS 
spectra confirmed the presence of $\mathrm{Ca}$ and $\mathrm{P}$ elements on the particle surface (Fig. 3(b)). Focusing on the Fe 2p region, a shake-up satellite of weak intensity was evidenced at $c a .720$ $\mathrm{eV}$. This is indicative of partial oxidation of the magnetite phase leading to the formation of small amounts of maghemite [24]. ICP and EDX indicated a Ca:P molar ratio of $1.7 \pm 0.1$, in good agreement with the expected value of 1.67 for HAp. In parallel, TGA measurements yielded to a $\mathrm{HAp}: \mathrm{C} / \mathrm{Fe}_{3} \mathrm{O}_{4}$ weight ratio of $1.1 \pm 0.1$ (Fig. 4(b)). Note that this ratio closely reflects the reaction conditions where $1 \mathrm{~g}$ of the $\mathrm{C} / \mathrm{Fe}_{3} \mathrm{O}_{4}$ powder was introduced in a solution containing $0.01 \mathrm{~mol} \mathrm{Ca}^{2+}$ and $0.006 \mathrm{~mol} \mathrm{PO}_{4}{ }^{3-}$ that should form $0.001 \mathrm{~mol}(1 \mathrm{~g})$ of HAp. This implies the HAp formation occurred only on the surface of the $\mathrm{C} / \mathrm{Fe}_{3} \mathrm{O}_{4}$ spheres.

Noticeably, such morphologies were obtained only for optimal L-aspartic acid and $\mathrm{Ca}^{2+} / \mathrm{PO}_{4}{ }^{3-}$ relative concentrations of $1 \mathrm{~mol} \mathrm{~L}^{-1}$ and $0.5 / 0.03 \mathrm{~mol} \mathrm{~L}^{-1}$ respectively. A smaller or larger amount of L-aspartic acid led to the presence of excess HAp in the solution or dissolution of $\mathrm{Fe}_{3} \mathrm{O}_{4}$, respectively. An insufficient or excess amount of calcium/phosphate led to composites with ill-defined morphologies. This underlines the key role of the aspartate pre-coating on favoring HAp formation on the microsphere surface. The biomimetic approach used here is inspired from mineralization processes found in several organisms, and especially described for the formation of aragonite $\left(\mathrm{CaCO}_{3}\right)$ nacreous shells [25]. It relies on the presence of proteins rich in aspartic acid moieties deposited on a rigid organic matrix. When calcium ions are present in the medium, they have a strong tendency to adsorb on the acidic layer where they are chelated by the carboxylate groups. This provides a reactive surface for further deposition of incoming carbonate ions, favoring calcium carbonate nucleation. Such experiments could be replicated in vitro and extended to other rigid substrates and other mineral phases [26]. If the density of acidic groups on the surface is not sufficient and/or calcium ions are in excess, then mineral precipitation can occur in solution, independently of the templating substrate. Here it was also observed that an excess of aspartic acid is able to dissolve the iron oxide nanoparticles, plausibly because of its strong chelating properties, as 
already demonstrated for oxalic acid [27]. However we found out that, once optimal concentrations have been determined, the procedure was highly reproducible in terms of mineralization rate and HAp nanocrystal dimensions.

VSM measurements showed that the two composites exhibited a similar hysteresis curve with a coercivity of $235 \mathrm{Oe}\left(\right.$ Fig. 4(a)). The saturation magnetization $(M s)$ was is $28 \mathrm{emu}^{-1}$ for $\mathrm{C} / \mathrm{Fe}_{3} \mathrm{O}_{4}$, and 14 emu $\mathrm{g}^{-1}$ for $\mathrm{HAp} @ \mathrm{C} / \mathrm{Fe}_{3} \mathrm{O}_{4}$, in good agreement with the 1:1 weight ratio for $\mathrm{HAp}: \mathrm{C} / \mathrm{Fe}_{3} \mathrm{O}_{4}$. In terms of porosity, the two composites exhibited a type IV hysteresis for $\mathrm{N}_{2}$ sorption, indicating the presence of mesopores (Fig. 4(c)). Application of the BET model indicates that $\mathrm{C} / \mathrm{Fe}_{3} \mathrm{O}_{4}$ has relatively high specific surface area $\left(\right.$ ca. $\left.330 \mathrm{~m}^{2} \mathrm{~g}^{-1}\right)$ and porous volume (ca. $\left.0.20 \mathrm{~cm}^{3} \mathrm{~g}^{-1}\right)$. Interestingly, HAp@ $\mathrm{C} / \mathrm{Fe}_{3} \mathrm{O}_{4}$ exhibits larger specific surface area (ca. $355 \mathrm{~m}^{2} \mathrm{~g}^{-1}$ ) and porous volume (ca. $0.30 \mathrm{~cm}^{3} \mathrm{~g}^{-1}$ ). For $\mathrm{C} / \mathrm{Fe}_{3} \mathrm{O}_{4}$, pore size distribution calculated from the $\mathrm{BJH}$ model on the desorption branch suggested the preponderance of mesopores with an average diameter of $4 \mathrm{~nm}$ and a significant amount of micropores that should mainly originate from the carbonization of glucose (Fig. 4(d)) [20]. For HAp@C/ $/ \mathrm{Fe}_{3} \mathrm{O}_{4}$, the mineral layer decreases the accessibility of the mesopores of the microsphere but induces the presence of larger mesopores in the 4-10 nm size range. These mesopores should correspond to inter-particle porosity inside the HAp coating, as previously reported [23].

\subsection{Removal studies}

To test the adsorption capacities of the composite microspheres, ampicillin, $\mathrm{La}^{3+}, \mathrm{Hg}^{2+}$ and $\mathrm{Pb}^{2+}$ were selected as representative organic and inorganic contaminants (Fig. 5). Based on preliminary kinetics experiments (see Supplementary material), the sorption isotherms were obtained after $24 \mathrm{~h}$ of contact between the sorbent powders and the solutions.

Ampicillin is a widespread drug that accumulates in the environment due to its low biodegradability, leading to the proliferation of antibiotic-resistant bacteria [28]. It is mainly 
in a zwitterionic molecular form between $\mathrm{pH} 3$ and $\mathrm{pH}$ 7.2. HAp showed no ampicillin removal capacity whereas $\mathrm{C} / \mathrm{Fe}_{3} \mathrm{O}_{4}$ exhibited a maximum removal capacity of $c a .0 .04 \mathrm{mmol}$ $\mathrm{g}^{-1}$ (Fig. 5(a)). The HAp@ $\mathrm{C} / \mathrm{Fe}_{3} \mathrm{O}_{4}$ composites partially inherited the ampicillin adsorption capacity from $\mathrm{C} / \mathrm{Fe}_{3} \mathrm{O}_{4}$ and showed a maximum removal capacity of $c a$. $0.01 \mathrm{mmol} \mathrm{g}$. Analyses of the experimental data using the Langmuir and Freundlich models are presented in Table 1 and Table 2 and the calculated curves are shown in Fig. 5(a). Correlation coefficients $\left(\mathrm{R}^{2}\right)$ were similar for the two equations but the low value of the $1 / n$ parameters as well as the apparent underestimation of the maximal sorption capacity by the Freundlich model suggest that the Langmuir model is more adapted to reproduce the experimental data.

Previous investigations of ampicillin sorption on activated carbons have suggested that the surface interactions were mainly of electrostatic nature [29]. Most carbons have points of zero charge (PZC) of $c a .8$ whereas magnetite has a PZC of $c a .6 .5$ [30], so that the microspheres are expected to bear a positive charge at $\mathrm{pH}=6$. In these conditions, ampicillin co-exists in two forms, zwitterionic and cationic. Therefore, sorption via attractive electrostatic interactions is the most plausible mechanism for ampicillin retention by the $\mathrm{C} / \mathrm{Fe}_{3} \mathrm{O}_{4}$ surface. HAp particles have PZC values in the 6-7 $\mathrm{pH}$ range [31] and their surface is therefore slightly negatively charged or neutral in the conditions of the experiments, with low affinity for ampicillin. In this context, it is interesting to calculate the maximum removal capacity for the $\mathrm{C} / \mathrm{Fe}_{3} \mathrm{O}_{4}$ part of the composites. Considering the $1: 1$ weight ratio between $\mathrm{HAp}$ and $\mathrm{C} / \mathrm{Fe}_{3} \mathrm{O}_{4}$ in the composite, the adsorption capacity per $\mathrm{g}$ of $\mathrm{C} / \mathrm{Fe}_{3} \mathrm{O}_{4}$ within the composite structure was ca. $0.02 \mathrm{mmol} \mathrm{g}^{-1}$, i.e. half the value obtained for the bare microspheres. Therefore these results suggest that the antibiotic is mainly adsorbed on the uncoated fraction of the $\mathrm{C} / \mathrm{Fe}_{3} \mathrm{O}_{4}$ surface.

Considering the wide importance of rare-earth ions in current technological devices and the related questions in terms of their environmental impact [32], the removal of $\mathrm{La}^{3+}$ by the composite microspheres was investigated. $\mathrm{C} / \mathrm{Fe}_{3} \mathrm{O}_{4}$ demonstrated no significant $\mathrm{La}^{3+}$ 
adsorption capability whereas the maximum removal capacity of HAp towards this species was ca. $2.10 \mathrm{mmol} \mathrm{g}^{-1}$ (Fig. 5(b)). The composite powder exhibited a maximum removal capacity of $c a$. $0.95 \mathrm{mmol} \mathrm{g}^{-1}$. Interestingly, when calculated per $\mathrm{g}$ of HAp, the $\mathrm{HAp} @ \mathrm{C} / \mathrm{Fe}_{3} \mathrm{O}_{4}$ composites has a removal capacity of $c a .1 .90 \mathrm{mmol} \mathrm{g}^{-1}$ that is very similar to the pure hydroxyapatite powder. This indicates that the deposition of the HAp nanocrystals on the microsphere surface does not significantly decrease their capacity to interact with $\mathrm{La}^{3+}$. Neither the Langmuir nor Freundlich model could reproduce the experimental data (as indicated by low $\mathrm{R}^{2}$ values in Table 1 and Table 2), indicating that the depletion in $\mathrm{La}^{3+}$ from the solution was not a simple adsorption process. Interestingly, XRD data obtained with HAp alone in the presence of $\mathrm{La}^{3+}$ evidenced the formation of lanthanum phosphate $\left(\mathrm{LaPO}_{4}\right)$. Analysis of the supernatant content at the end of the sorption experiments indicated a molar ratio of 0.6 between the retained $\mathrm{La}^{3+}$ and the released $\mathrm{Ca}^{2+}$ whereas the $\mathrm{P}$ element could not be detected. Considering the HAp and $\mathrm{LaPO}_{4}$ stoichiometry, the release of 10 calcium ions from hydroxyapatite should be concomitant with the departure of 6 phosphate species, that can precipitate 6 lanthanum ions. Therefore, it is possible to propose that surface dissolution of poorly crystalline hydroxyapatite in contact with water leads to $\mathrm{Ca}^{2+}$ and $\mathrm{PO}_{4}{ }^{-}$release, the latter being able to precipitate $\mathrm{LaPO}_{3}$ and depleting the solution in $\mathrm{La}^{3+}$.

The retention of two widespread highly toxic heavy metals, $\mathrm{Hg}^{2+}$ and $\mathrm{Pb}^{2+}$, was also studied. Pristine $\mathrm{HAp}$ and $\mathrm{C} / \mathrm{Fe}_{3} \mathrm{O}_{4}$ were able to remove both ions from aqueous solutions, in agreement with the literature [33-35], but to a different extent. For $\mathrm{Pb}^{2+}, \mathrm{HAp}$ alone has a maximal removal capacity of $c a .1 .20 \mathrm{mmol} \mathrm{g}^{-1}, \mathrm{C} \mathrm{Fe}_{3} \mathrm{O}_{4}$ of $c a .0 .05 \mathrm{mmol} \mathrm{g}^{-1}$ and the composite showed a slight improvement compared to HAp ( $c a .1 .40 \mathrm{mmol} \mathrm{g}^{-1}$ ). Analyses of the experimental data by both Langmuir and Freundlich models showed acceptable $\mathrm{R}^{2}$ values but the $1 / \mathrm{n}$ values were small. In parallel, the XRD diffractograms show distinct peaks that can be attributed to hydroxypyromorphite $\left(\mathrm{Hpy}, \mathrm{Pb}_{10}\left(\mathrm{PO}_{4}\right)_{6}(\mathrm{OH})_{2}\right)$. The molar ratio of released $\mathrm{Ca}^{2+}$ : removed $\mathrm{Pb}^{2+}$ in the supernatant was almost 1 and no phosphorus could be 
detected by ICP. Taken together, these data are in favor of a mechanism involving the adsorption of $\mathrm{Pb}^{2+}$ on the HAp surface. Then two possibilities exist: a cation exchange reaction between $\mathrm{Pb}^{2+}$ ions in aqueous solution and $\mathrm{Ca}^{2+}$ ions of HAp or surface dissolution and rapid reprecipitation of $\mathrm{HPy}$.

For $\mathrm{Hg}^{2+}$, the maximum removal capacity for $\mathrm{HAp}$ and $\mathrm{C} / \mathrm{Fe}_{3} \mathrm{O}_{4}$ were similar $(c a .0 .20 \mathrm{mmol}$ $\mathrm{g}^{-1}$ ) while the composite $\mathrm{HAp} @ \mathrm{C} / \mathrm{Fe}_{3} \mathrm{O}_{4}$ showed significantly improved performances ( $c a$. $0.30 \mathrm{mmol} \mathrm{g}^{-1}$ ). On the XRD patterns of the pure HAp powder after contact with $\mathrm{Hg}^{2+}$, no obvious crystalline phase was detected although slight modification of the patterns in the $2(=$ 28-29 ${ }^{\circ}$ domain may indicate the formation of $\mathrm{Hg}_{3}\left(\mathrm{PO}_{4}\right)_{2}$ (Fig. 3). From the ICP data, the molar ratio between removed $\mathrm{Hg}^{2+}$ and released $\mathrm{Ca}^{2+}$ is $\mathrm{ca}$. 0.2. As mentioned earlier, the release of 10 calcium ions upon HAp dissolution is associated with the release of 6 phosphate ions that may precipitate up to $9 \mathrm{Hg}^{2+}$ species, a value that is far above the measured ratio. However, it must be taken into account that the $\mathrm{C} / \mathrm{Fe}_{3} \mathrm{O}_{4}$ spheres also contribute to the removal of mercury ions. Interestingly, only the Freundlich model was found suitable to reproduce the experimental data, with reasonable $\mathrm{R}^{2}$ and $1 / n$ values. This reflects the heterogenous nature of the sorbing phase that combines the carbon and the HAp surfaces.

Additional metal removal experiments were performed at $\mathrm{pH} 4$ and $\mathrm{pH} 8$ (Table 3). The evolution of mercury removal with $\mathrm{pH}$ indicates that acidic conditions are particularly detrimental to the $\mathrm{C} / \mathrm{Fe}_{3} \mathrm{O}_{4}$ spheres. This can be attributed to the increased solubility of magnetite with decreasing $\mathrm{pH}$, as confirmed by the detection of high levels of $\mathrm{Fe}$ in the supernatant. In contrast, the effect of $\mathrm{pH}$ on $\mathrm{La}^{3+}$ removal suggests that basic conditions decrease the reactivity of HAp. This can be correlated with the decrease solubility of HAp with increasing $\mathrm{pH}$, as confirmed by the measured lower calcium content of the supernatant compared to $\mathrm{pH}$ 6. Interestingly, the $\mathrm{Pb}^{2+}$ removal was almost unaffected by $\mathrm{pH}$ variations neither for HAp nor for the composite. Hence, coming back to the proposed mechanisms 
explaining HPy formation, this result is more in favor of a cation-exchange process than a dissolution/reprecipitation reaction.

Indeed, it is not possible to identify what is the relative amount of sorbed $\mathrm{Hg}^{2+}$ and $\mathrm{Pb}^{2+}$ on the two components of the composite spheres but the removal capacities of the two individual phases suggest a higher reactivity of the hydroxyapatite layer towards these metals. This is in agreement with the literature showing that similar hydroxyapatite nanolayers can have higher sorption capacity than the HAp powder alone due to lower crystallinity and smaller crystallite size [23]. Therefore it can be suggested that the increased capacity for $\mathrm{Hg}^{2+}$ and $\mathrm{Pb}^{2+}$ binding of the composite materials compared to the two individual phases originates from wellcontrolled architecture of the nanocomposites.

From a practical perspective, the here-described composites appear particularly well-adapted for the simultaneous removal of species with distinct affinities for carbon and hydroxyapatite. For instance, HAp has a low affinity for antibiotics (ca. $2 \mathrm{mg} \cdot \mathrm{g}^{-1}$ for related compounds [36]) while carbons poorly bind $\mathrm{La}^{3+}$ ions (ca. $0.05 \mathrm{mg} . \mathrm{g}-1$ [37]). Our experiments suggest the composite approach can be advantageous provided an adjustment of the C:HAp weight ratio as well as a variation of microsphere size or porosity via modulation of the processing parameters. The question is raised about the possible competition between the sorption of organic and inorganic pollutants, a phenomenon that is particularly relevant for the cleaning of natural waters that can contain fulvic and humic acids. Although such a possibility should be taken into account, it is important to point out that the outer layer of the composite consist of the hydroxyapatite phase that has low affinity for organics. Therefore the organic content of natural waters may interfere with the immobilization of organic pollutants but not significantly with the retention of metal ions. In parallel, it is interesting to consider species such as $\mathrm{Hg}^{2+}$ that have good affinities for both the carbon surface and the hydroxyapatite layer. The retention ability of activated carbons towards mercury in conditions comparable to this work was reported to range between $0.01 \mathrm{mg} \mathrm{g}^{-1}$ and $100 \mathrm{mg} \mathrm{g}^{-1}[38,39]$. However, the 
highest values are obtained for materials with much higher specific surface area $\left(1100 \mathrm{~m}^{2} \mathrm{~g}^{-1}\right.$, i.e. three time higher than the microspheres). For hydroxyapatite, reported values vary between $0.5 \mathrm{mg} \mathrm{g}^{-1}$ and $50 \mathrm{mg} \mathrm{g}^{-1}$ (in column experiments) [34]. Therefore the composite phases with removal capacities of $c a .2 \mathrm{mg} \mathrm{g}^{-1}$ are in the lower range of efficiency. Yet, the here-demonstrated increase in removal performance of the composite compared to its individual components suggests that extension of the presented strategy to other carbonaceous supports would be of particular interest.

\section{Conclusions}

We demonstrate that multi-phasic materials consisting of hydroxyapatite-coated iron oxidedecorated carbon microspheres prepared from cheap, environment-friendly sources, in solvent-free conditions exhibit the ability to remove both organic and inorganic pollutants from aqueous solutions. Of particular interest is the observation that the composite sorption capacities may exceed that of its individual components, as illustrated here by $\mathrm{Hg}^{2+}$ and $\mathrm{Pb}^{2+}$. Noticeably thanks to the presence of iron oxide nanoparticles, the composite microspheres can be easily and fully recovered by application of a magnetic field, making them particularly promising as sorbing seeds for superconducting magnetic separation or biological application.

\section{Acknowledgments}

Huihui Yang and Laifeng Li acknowledge funding support from the National Natural Science Foundation of China (Grant No. Y4B30471E4).

\section{Supplementary informations}

Kinetics of ampicillin, $\mathrm{La}^{3+}, \mathrm{Hg}^{2+}$ and $\mathrm{Pb}^{2+}$ removal by $\mathrm{HAp} @ \mathrm{C} / \mathrm{Fe}_{3} \mathrm{O}_{4}$ composites 


\section{References}

[1] J. Yang, H. W. Zhang, M. H. Yu, I. Emmanuelawati, J. Zou, Z. G. Yuan, C. Z. Yu, Highcontent, well-dispersed $\gamma-\mathrm{Fe}_{2} \mathrm{O}_{3}$ nanoparticles encapsulated in macroporous silica with superior arsenic removal performance, Adv. Funct. Mater. 24 (2014) 1354-1363.

[2] G. Crini, Recent developments in polysaccharide-based materials used as adsorbents in wastewater treatment, Prog. Polym. Sci. 30 (2005) 38-70.

[3] M. J. Martin, A. Artola, M. D. Balaguer, M. Rigola, Activated carbons developed from surplus sewage sludge for the removal of dyes from dilute aqueous solutions, Chem. Engin. J. 94 (2003) 231-239.

[4] T. A. Kurniawan, G. Y. S. Chan, W. H. Lo, S. Babel, Physicochemical treatment techniques for wastewater laden with heavy metals, Chem. Engin. J. 118 (2006) 83-98.

[5] J. D. Lee, S. H. Lee, M. H. Jo, P. K. Park, C. H. Lee, J. W. Kwak, Effect of coagulation conditions on membrane filtration characteristics in coagulation-microfiltration process for water treatment, Environ. Sci. Technol. 34 (2000) 3780-3788.

[6] H. A. Elliott, B. A. Dempsey, P. J. Maille, Content and Fractionation of Heavy Metals in Water Treatment Sludges, J. Environ Quality 19 (1990) 330-334

[7] T. Ohara, H. Kumakura, H. Wada, Magnetic separation using superconducting magnets, Physica C : Supercond. 357 (2001) 1272-1280.

[8] S. Igarashi, N. Nomura, F. Mishima, Y. Akiyama, S. Nishijima, Study on magnetic separation for decontamination of cesium contaminated soil by using superconducting magnet, Physica C : Supercond. 504 (2014) 144-147.

[9] R. D. Ambashta, M. Sillanpää, Water purification using magnetic assistance: A review, J. Hazard. Mater. 180 (2010) 38-49.

[10] R. A. Crane, T. B. Scott, Nanoscale zero-valent iron: future prospects for an emerging water treatment technology, J. Hazard. Mater. 211 (2012) 112-125. 
[11] P. Xu, G. M. Zeng, D. L. Huang, C. L. Feng, S. Hu, M. H. Zhao, C. Lai, Z. Wei, C. Huang, G. X. Xie, Z. F. Liu, Use of iron oxide nanomaterials in wastewater treatment: A review, Sci Total Environ. 424 (2012) 1-10.

[12] J. Fei, Y., J. Zhao, L. Gao, Y., J. Li, Large-scale preparation of 3D self-assembled iron hydroxide and oxide hierarchical nanostructures and their applications for water treatment, J. Mater. Chem. 21 (2011) 11742-11746.

[13] H. Zhang, Z. Zhao, X. Xu, L. Li, Study on industrial wastewater treatment using superconducting magnetic separation, Cryogenics 51 (2011) 225-228..

[14] A. Nzihou, P. Sharrock, Role of phosphate in the remediation and reuse of heavy metal polluted wastes and sites, Waste Biomass. Valor. 1 (2010) 163-174.

[15] J. Rivera-Utrilla, M. Sanchez-Polo, V. Gomez-Serrano, P.M. Alvarez, M.C.M. AlvimFerraz, J.M. Dias, Activated carbon modifications to enhance its water treatment applications. An overview, J. Hazard Mater.178 (2010) 1-23.

[16] L. C. A. Oliveira, R. V. R. Rios, A. J. D. Fabris, V. Garg, K. Sapag, R. M. Lago, Activated carbon/iron oxide magnetic composites for the adsorption of contaminants in water, Carbon 40 (2002) 2177-2083.

[17] D. Zhang, S. Wei, C. Kaila, X. Su, J. Wu, A. B. Karki, P. D. Young, Z. Guo, Carbonstabilized iron nanoparticles for environmental remediation, Nanoscale 2 (2010) 917-919.

[18] L. Dong, Z. Zhu, Y. Qiu, J. Zhao, Removal of lead from aqueous solution by hydroxyapatite/magnetite composite adsorbent, Chem. Engin. J. 165 (2010) 827-834.

[19] H. H. Yang, S. Masse, M. Rouelle, E. Aubry, Y. Li, C. Roux, Y. Journaux, L. F. Li, T. Coradin, Magnetically recoverable iron oxide-hydroxyapatite nanocomposites for lead removal, Int. J. Environ. Sci. Technol. 12 (2015) 1173-1182.

[20] W. H. Suh, K. S. Suslick, Magnetic and porous nanospheres from ultrasonic spray pyrolysis, J. Am. Chem. Soc. 34 (2005) 12007-12010. 
[21] S. E. Skrabalak, K. S. Suslick, Porous carbon powders prepared by ultrasonic spray pyrolysis, J. Am. Chem. Soc. 128 (2006) 12642-12643.

[22] I.-M. Tang, N. Krishnamara, N. Charoenphandhu, R. Hoonsawat, W. Pon-On, Biomagnetic of apatite-coated cobalt ferrite: A core-shell particle for protein adsorption and pH-controlled release, Nanoscale Res. Lett. 6 (2011) 19

[23] H. H. Yang, S. Masse, H. Zhang, C. Hélary, L. F. Li, T. Coradin, Surface reactivity of hydroxyapatite nanocoatings deposited on iron oxide magnetic spheres toward toxic metals, J. Colloid Interface Sci. 417 (2014) 1-8.

[24] A. P. Grosvenor, B. A. Kobe, M. C. Biesinger, N. S. Mc Intyre, Investigation of multiplet splitting of Fe 2p XPS spectra and bonding in iron compounds, Surf. Interface Anal. 36 (2004) 1564-1574.

[25] G. Falini, S. Albeck, S. Weiner, L. Addadi, Control of Aragonite or Calcite Polymorphism by Mollusk Shell Macromolecules, Science, 271 (1996) 67-69

[26] A.-W. Xu, Y. Ma, H. Cölfen, Biomimetic mineralization, J. Mater. Chem. 17 (2007) 415449

[27] D. Panias, M. Taxiarchou, I. Paspaliaris, A. Kontopoulos, Mechanisms of dissolution of iron oxides in aqueous oxalic acid solutions, Hydrometallurgy 42 (1996) 257-265

[28] F. Baquero, J.-L. Martinez, R. Canton, Antibiotics and antibiotic resistance in water environments, Curr. Opin. Biotechnol. 19 (2008) 260-265.

[29] G. Wang, T. Wu, Y. Li, D. Sun, Y. Wang, X. Huang, G. Zhang, R. Liu, Removal of ampicillin sodium in solution using activated carbon adsorption integrated with $\mathrm{H}_{2} \mathrm{O}_{2}$ oxidation, J. Chem. Technol. Biotechnol. 87 (2012) 623-628

[30] M. Kosmulski, pH-dependent surface charging and points of zero charge. IV. Update and new approach, J. Colloid Interface Sci. 337 (2009) 439-448.

[31] T. S. B. Narasaraju, D. E Phebe, Some physico-chemical aspects of hydroxylapatite, J. Mater. Sci. 31 (1996) 1-21. 
[32] J. M. Barry, B. J. Meehan, The acute and chronic toxicity of lanthanum to daphnia carinata, Chemosphere 41 (2000) 1669-1674.

[33] Y. Xu, F. W. Schwartz, Lead immobilization by hydroxyapatite in aqueous solutions, J. Contamin Hydrol. 15 (1994) 187-206.

[34] J. Oliva, J. D. Pablo, J. L. Cortina, J. Cama, C. Ayora, Removal of cadmium, copper, nickel, cobalt and mercury from water by Apatite II (TM): column experiments, J. Hazard. Mater. 194 (2011) 312-323.

[35] K. Kadirvelu, K. Thamaraiselvi, C. Namasivayam, Removal of heavy metals from industrial wastewaters by adsorption onto activated carbon prepared from an agricultural solid waste, Bioresource Technol. 76 (2001) 63-65.

[36] H. Bouyarmane, I. El Hanbali, M. El Karbane, A. rami, A. Saoiabi, S. Saoiabi, S. Masse, T. Coradin, A. Laghzizil, Parameters influencing ciprofloxacin, ofloxacin, amoxicillin and sulfamethoxazole retention by natural and converted calcium phosphates, J. Hazard. Mater. $291(2015) 38-44$

[37] D. S. R. Murty, G. Chakrapani, Preconcentration of rare earth éléments on activated carbon and its application to groundwater and sea-water analysis, J. A. A. S. 11 (1996) 815 820

[38] M.F. Yardim, T. Budinova, E. Ekinci, N. Petrov, M. Razvigorona, V. Minkova, Removal of mercury (II) from aqueous solution by activated carbon obtained from furfural, Chemosphere 52 (2003) 835-841

[39] F.-S. Zhang, J. O. Nriagu, H. Itoh, Mercury removal from water using activated carbons derived from organic sewage sludge, Water Res. 39 (2005) 389-395. 


\section{Figure Captions}

Fig. 1. Overview of the synthetic route to hydroxyapatite-coated magnetic carbon microspheres: carbon microspheres (light brown) decorated with magnetite nanoparticles (white) are first coated with aspartic acid (green), allowing for further deposition of hydroxyapatite nanocrystal (light purple)

Fig. 2. SEM and TEM images of (a,c,e) $\mathrm{C} / \mathrm{Fe}_{3} \mathrm{O}_{4}$ and (b,d,f) $\mathrm{HAp} @ \mathrm{C} / \mathrm{Fe}_{3} \mathrm{O}_{4}$ powders. Left hand column : $\mathrm{C} / \mathrm{Fe}_{3} \mathrm{O}_{4}$ samples consist of hollow (see inset) carbon microspheres decorated with magnetite particles. Right hand column: $\mathrm{HAp} @ \mathrm{C} / \mathrm{Fe}_{3} \mathrm{O}_{4}$ showed additional hydroxyapatite nanocrystals protruding from the microsphere surface.

Fig. 3. (a) XRD patterns of the $\mathrm{C} / \mathrm{Fe}_{3} \mathrm{O}_{4}$ and $\mathrm{HAp} @ \mathrm{C} / \mathrm{Fe}_{3} \mathrm{O}_{4}$ powders before and after $\mathrm{La}^{3+}$, $\mathrm{Hg}^{2+}$ and $\mathrm{Pb}^{2+}$ removal, with hydroxyapatite powder (HAp) as a reference; (b) XPS spectra of $\mathrm{C} / \mathrm{Fe}_{3} \mathrm{O}_{4}$ and $\mathrm{HAp} @ \mathrm{C} / \mathrm{Fe}_{3} \mathrm{O}_{4}$ powders, with focus on the $\mathrm{Fe} 2 \mathrm{p}$ region.

Fig. 4. (a) VSM measurements of magnetization curves at $298 \mathrm{~K}$ of the $\mathrm{C} / \mathrm{Fe}_{3} \mathrm{O}_{4}$ and HAp@C/ $\mathrm{Fe}_{3} \mathrm{O}_{4}$ powders. (b) TGA analyses of the composite powders. (c) $\mathrm{N}_{2}$-sorption porosimetry at $77 \mathrm{~K}$ and (d) pore size distribution obtained by the $\mathrm{BJH}$ model for the $\mathrm{C} / \mathrm{Fe}_{3} \mathrm{O}_{4}$ and $\mathrm{HAp} @ \mathrm{C} / \mathrm{Fe}_{3} \mathrm{O}_{4}$ powders.

Fig. 5. Removal capacity at equilibrium $\left(q_{e}\right)$ as a function of equilibrium concentration $\left(C_{e}\right)$ of (a) ampicilin, (b) $\mathrm{La}^{3+}$, (c) $\mathrm{Hg}^{2+}$ and (d) $\mathrm{Pb}^{2+}$ after $24 \mathrm{~h}$ of contact between hydroxyapatite (HAp), magnetic carbon $\left(\mathrm{C} / \mathrm{Fe}_{3} \mathrm{O}_{4}\right)$ and mineralized magnetic carbon powders (HAp@ $\left.\mathrm{C} / \mathrm{Fe}_{3} \mathrm{O}_{4}\right)$. Langmuir (-) and Freundlich (----) isotherms fitting curves are also provided. 
Table 1. Adsorption isotherm parameters obtained by Langmuir model.

\begin{tabular}{|c|c|c|c|c|c|c|c|c|c|c|c|c|}
\hline \multirow[t]{2}{*}{ Langmuir } & \multicolumn{2}{|c|}{ Ampicillin } & \multicolumn{4}{|c|}{$\mathrm{La}^{3+}$} & \multicolumn{3}{|c|}{$\mathrm{Hg}^{2+}$} & \multicolumn{3}{|c|}{$\mathrm{Pb}^{2+}$} \\
\hline & $\begin{array}{c}q_{\max } \\
\left(\mathrm{mmol} \mathrm{g}^{-1}\right)\end{array}$ & $\begin{array}{c}K_{l} \\
\left(\mathrm{~L} \mathrm{mg}^{-1}\right)\end{array}$ & $\mathrm{R}^{2}$ & $\begin{array}{c}q_{\max } \\
\left(\mathrm{mmol} \mathrm{g}^{-1}\right)\end{array}$ & $\begin{array}{c}\mathrm{K}_{1} \\
\left(\mathrm{~L} \mathrm{mg}^{-1}\right)\end{array}$ & $\mathrm{R}^{2}$ & $\begin{array}{c}q_{\max } \\
\left(\mathrm{mmol} \mathrm{g}^{-1}\right)\end{array}$ & $\begin{array}{c}\mathrm{K}_{1} \\
\left(\mathrm{~L} \mathrm{mg}^{-1}\right)\end{array}$ & $\mathrm{R}^{2}$ & $\begin{array}{c}q_{\max } \\
\left(\mathrm{mmol} \mathrm{g}^{-1}\right)\end{array}$ & $\begin{array}{c}\mathrm{K}_{1} \\
\left(\mathrm{~L} \mathrm{mg}^{-1}\right)\end{array}$ & $\mathrm{R}^{2}$ \\
\hline HAp & --- & --- & --- & $2.09 \pm 0.07$ & 1.42 & 0.84 & $0.20 \pm 0.03$ & 4.81 & 0.62 & $1.18 \pm 0.02$ & 4.16 & 0.99 \\
\hline $\mathrm{C} / \mathrm{Fe}_{3} \mathrm{O}_{4}$ & $0.040 \pm 0.001$ & 1.57 & 0.96 & --- & --- & --- & $0.20 \pm 0.03$ & 1.05 & 0.33 & $0.05 \pm 0.002$ & 0.37 & 0.94 \\
\hline $\mathrm{HAp} @ \mathrm{C} / \mathrm{Fe}_{3} \mathrm{O}_{4}$ & $0.010 \pm 0.002$ & 3.55 & 0.93 & $0.97 \pm 0.05$ & 0.16 & 0.76 & $0.30 \pm 0.03$ & 7.96 & 0.29 & $1.41 \pm 0.01$ & 2.31 & 0.99 \\
\hline
\end{tabular}


Table 2. Adsorption isotherm parameters obtained by Freundlich model.

\begin{tabular}{|c|c|c|c|c|c|c|c|c|c|c|c|c|}
\hline \multirow[t]{2}{*}{ Freundlich } & \multicolumn{3}{|c|}{ Ampicillin } & \multicolumn{3}{|c|}{$\mathrm{La}^{3+}$} & \multicolumn{3}{|c|}{$\mathrm{Hg}^{2+}$} & \multicolumn{3}{|c|}{$\mathrm{Pb}^{2+}$} \\
\hline & $\begin{array}{c}K_{f} \\
\left(\mathrm{mmol} \mathrm{g}^{-1}\right)\end{array}$ & $1 / n$ & $\mathrm{R}^{2}$ & $\begin{array}{c}K_{f} \\
\left(\mathrm{mmol} \mathrm{g}^{-1}\right)\end{array}$ & $1 / n$ & $\mathrm{R}^{2}$ & $\begin{array}{c}K_{f} \\
\left(\mathrm{mmol} \mathrm{g}^{-1}\right)\end{array}$ & $1 / n$ & & $\begin{array}{c}K_{f} \\
\left(\mathrm{mmol} \mathrm{g}^{-1}\right)\end{array}$ & $1 / n$ & $\mathrm{R}^{2}$ \\
\hline HAp & --- & --- & --- & 2.07 & 0.002 & 0.84 & 0.04 & 0.31 & 0.79 & 1.12 & 0.01 & 0.99 \\
\hline $\mathrm{C} / \mathrm{Fe}_{3} \mathrm{O}_{4}$ & 0.03 & 0.05 & 0.96 & --- & --- & --- & 0.01 & 0.49 & 0.81 & 0.04 & 0.05 & 0.95 \\
\hline $\mathrm{HAp} @ \mathrm{C} / \mathrm{Fe}_{3} \mathrm{O}_{4}$ & 0.01 & 0.01 & 0.93 & 0.79 & 0.04 & 0.77 & 0.02 & 0.49 & 0.86 & 1.28 & 0.02 & 0.99 \\
\hline
\end{tabular}


Table 3. Maximal experimental removal capacity $\left(q_{\max , e x}\right)$ at various $\mathrm{pH}$

\begin{tabular}{cccccccccc}
\hline & \multicolumn{3}{c}{$\mathrm{La}^{3+}$} & \multicolumn{3}{c}{$\mathrm{Hg}^{2+}$} & \multicolumn{3}{c}{$\mathrm{Pb}^{2+}$} \\
$\mathrm{pH}$ & 4 & 6 & 8 & 4 & 6 & 8 & 4 & 6 & 8 \\
\hline $\mathrm{HAp}$ & 1.56 & 2.09 & 1.42 & 0.20 & 0.20 & 0.22 & 1.18 & 1.18 & 1.19 \\
$\mathrm{C} / \mathrm{Fe}_{3} \mathrm{O}_{4}$ & ---- & ---- & ---- & 0.01 & 0.20 & 0.27 & 0.05 & 0.05 & 0.05 \\
$\mathrm{HAp} @ \mathrm{C} / \mathrm{Fe}_{3} \mathrm{O}_{4}$ & 0.90 & 1.01 & 0.65 & 0.26 & 0.30 & 0.32 & 1.39 & 1.41 & 1.43 \\
\hline
\end{tabular}




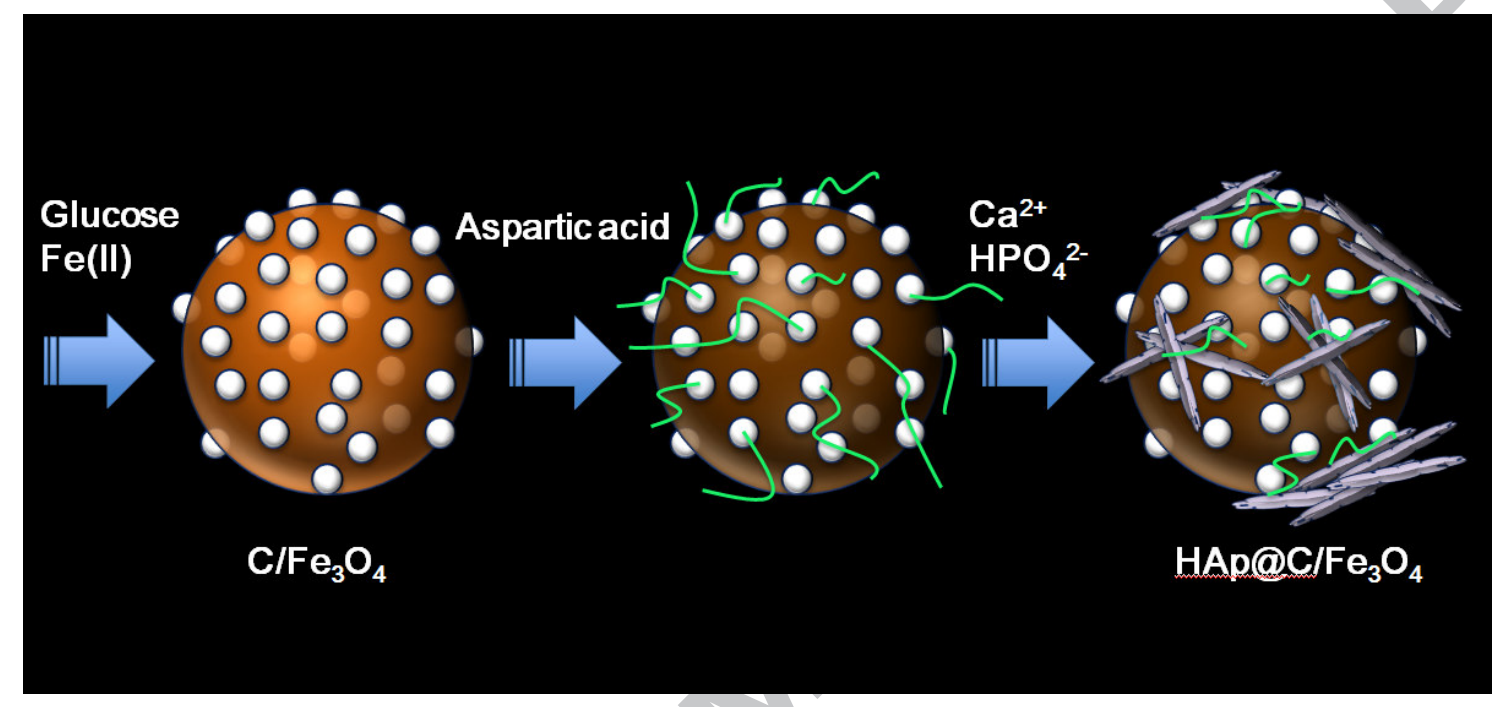

Fig. 1 

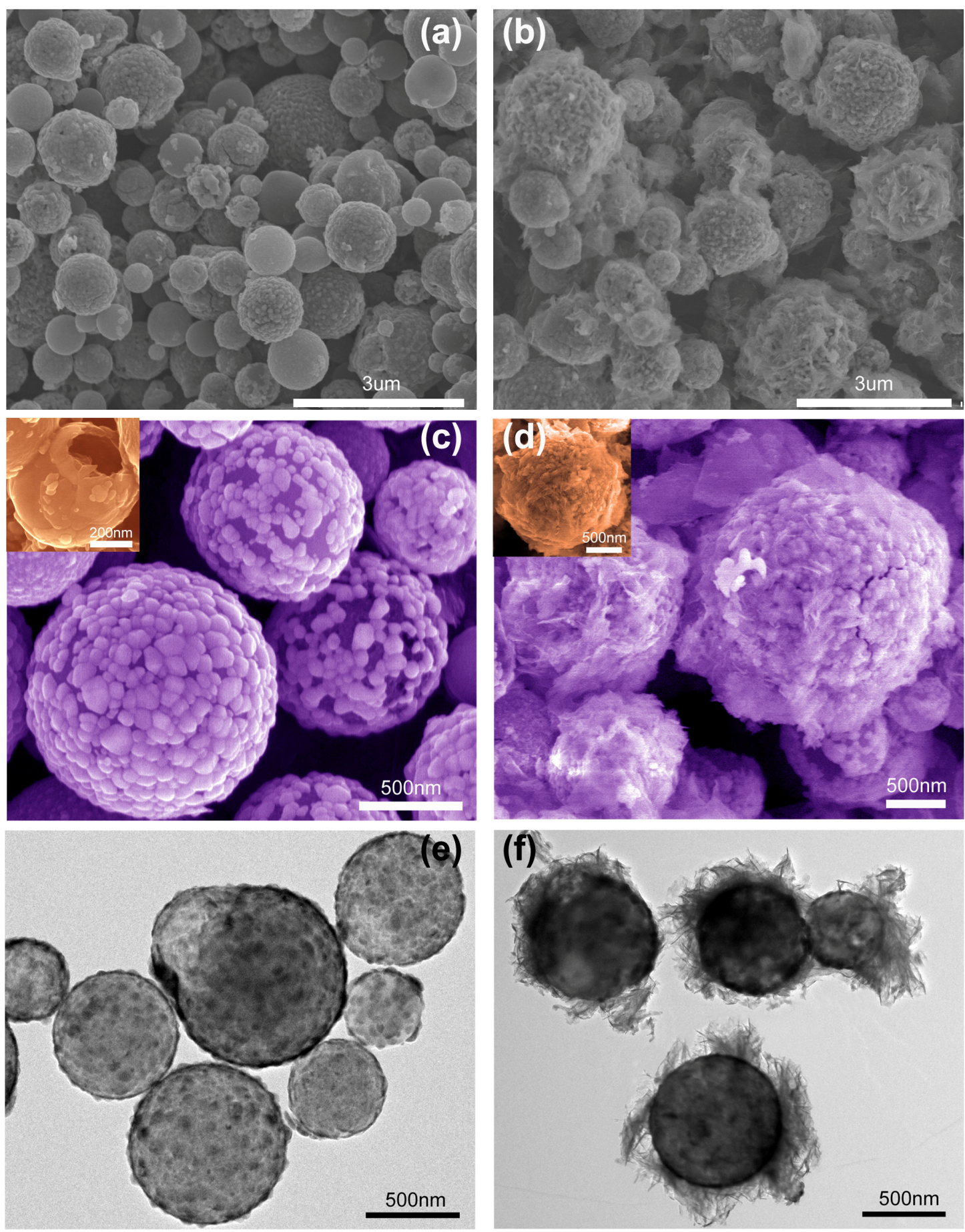

Fig. 2. 
(a)

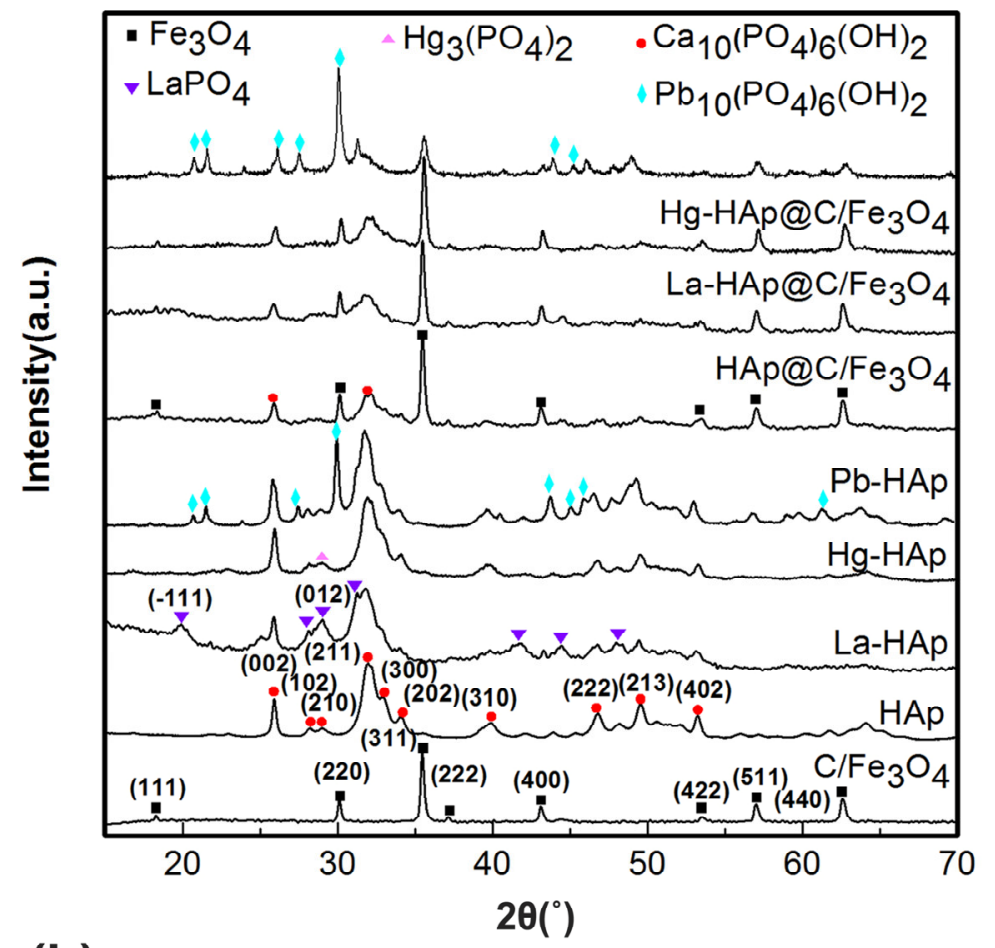

(b)

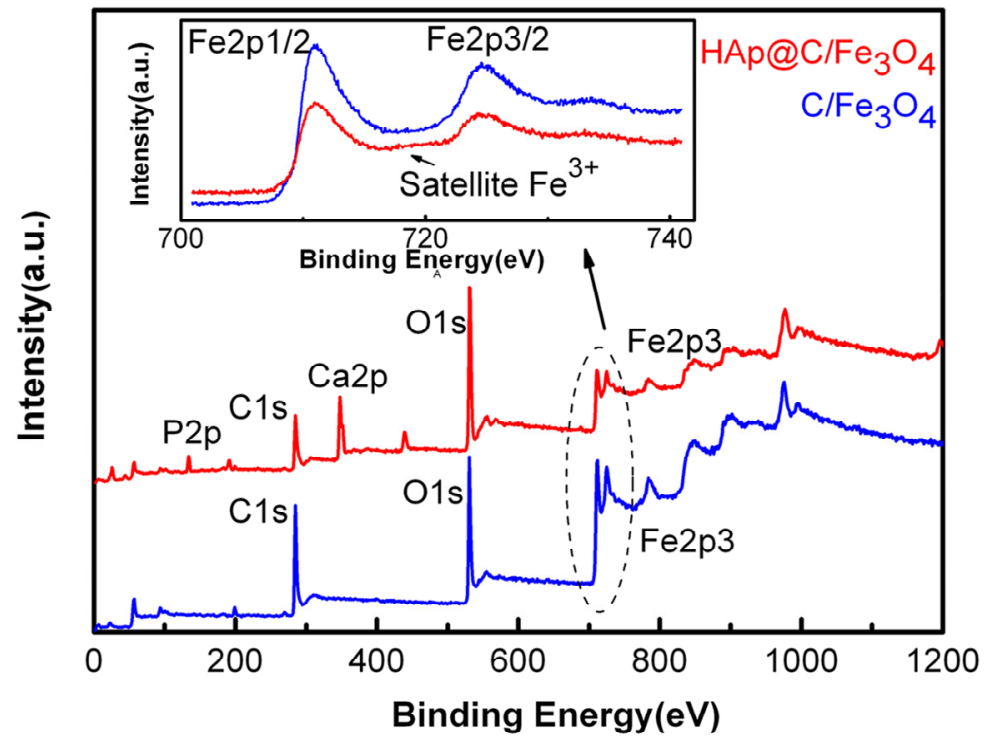

Fig. 3 

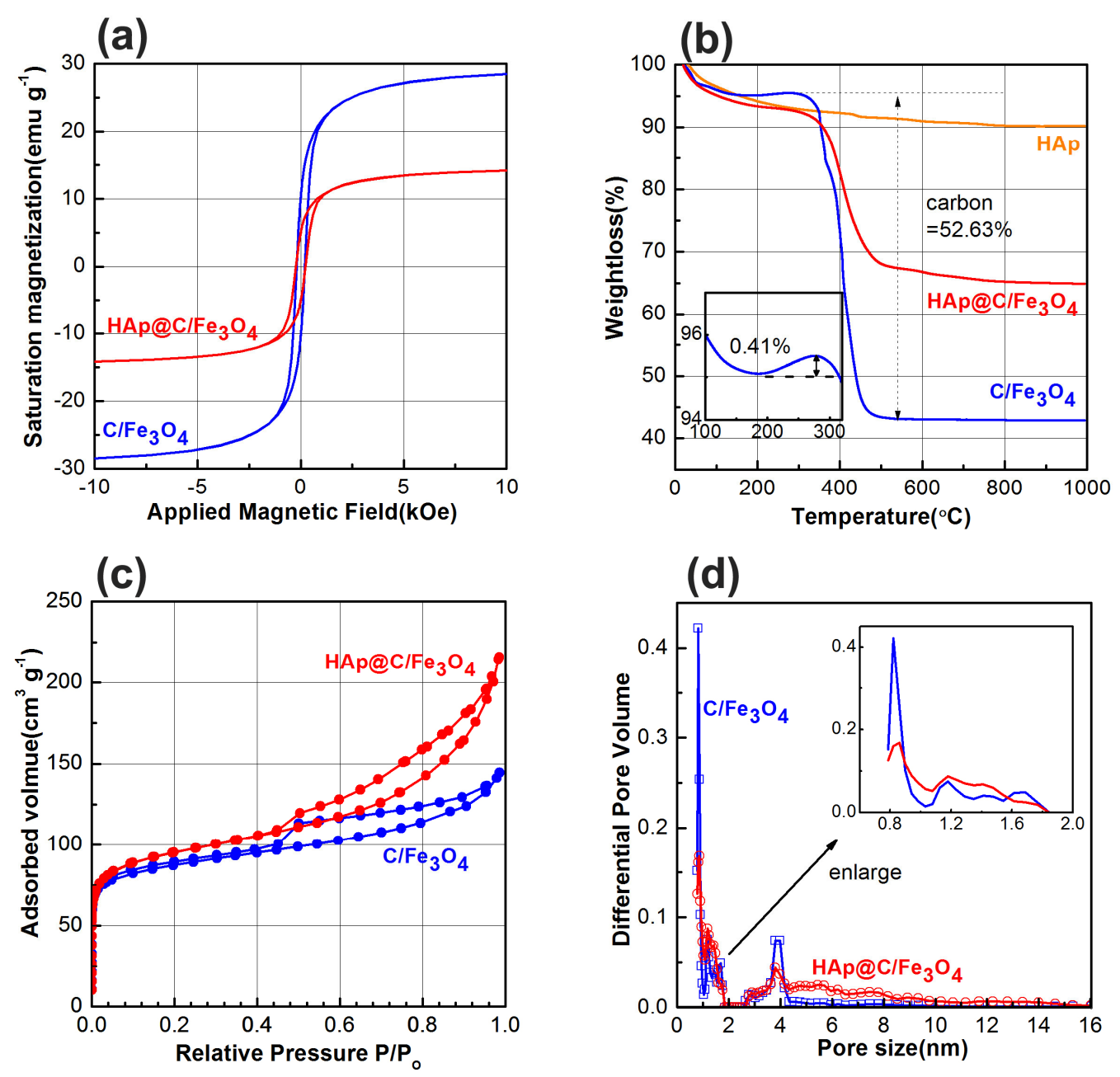

Fig. 4. 
(a)

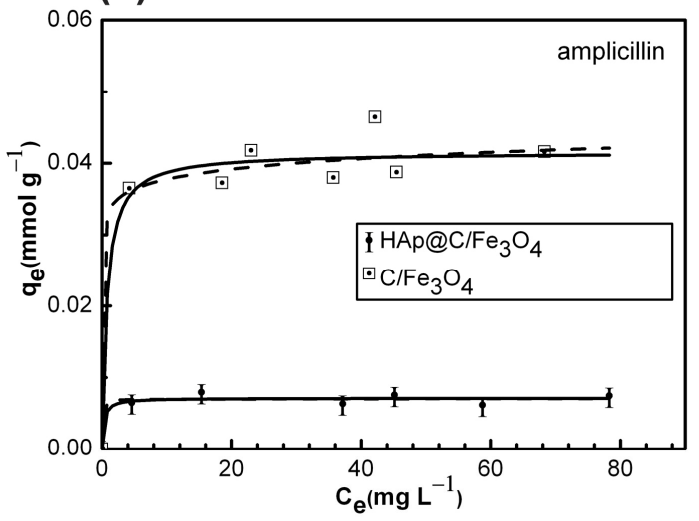

(c)

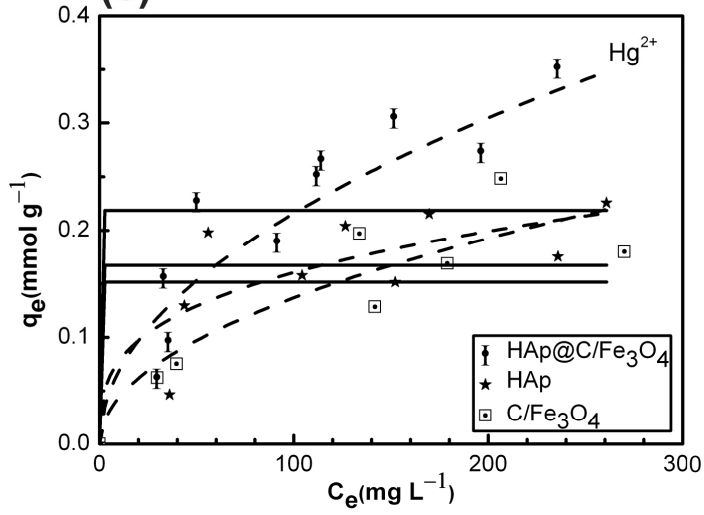

(b)

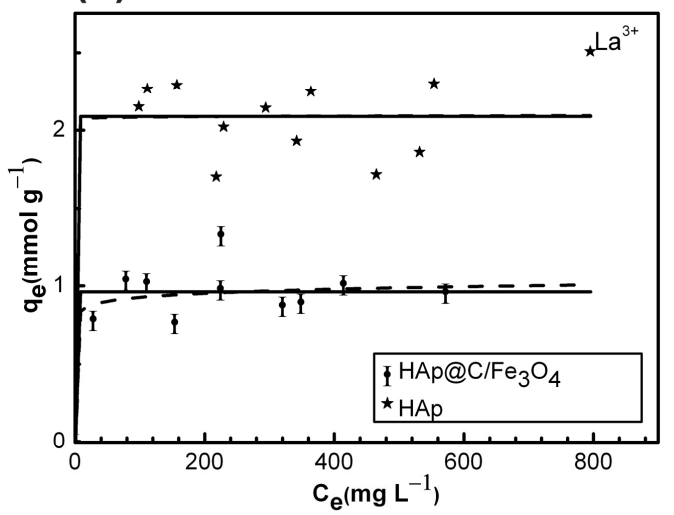

(d)

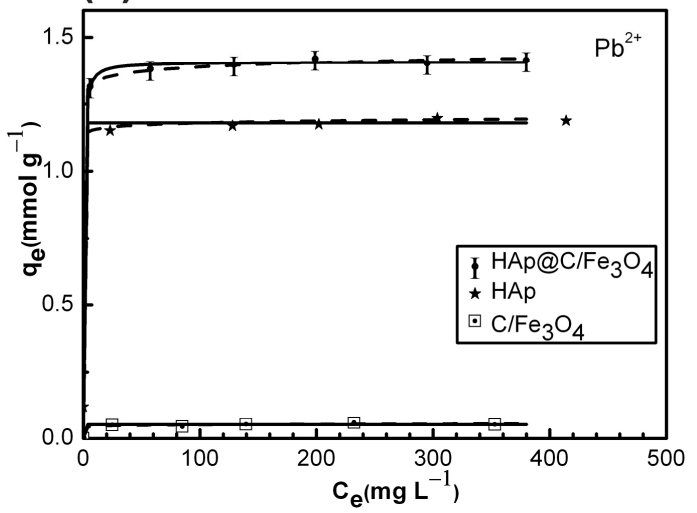

Fig. 5. 


\section{Highlights}

$>$ Hierarchically-organized apatite/iron oxide/carbon microspheres were developed

$>$ The micro/mesoporous powders combine the sorption capacities of carbon and apatite

$>$ They demonstrate adsorption capacity towards organic and inorganics pollutants

$>$ These composites can be useful for superconducting separation wastewater treatment 


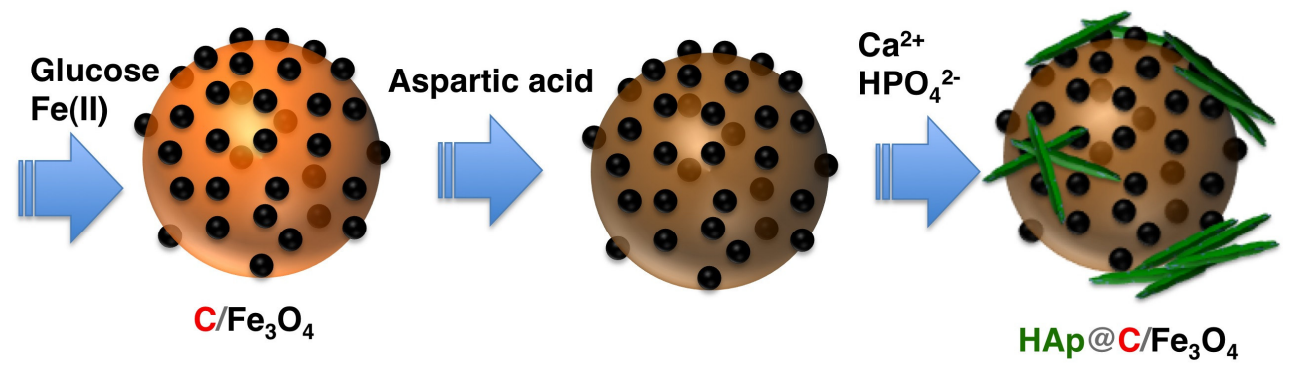

